But the situation in Europe is now gradually changing as people's relationship to history is transformed. In the post-modern world, people's relationship to 'their' past is less connected and more obviously constructed The issue of ownership of the past is less self-evident in increasingly multi-racial and ethnically diverse states. The presentation of the past is linked to all forms of image consciousness and manipulation. New institutions exist for the rethinking of history - whether they be EuroDisney or feminist movements. Particularly in museums and heritage parks, the major question is 'what message shall we write?' and the socral implications of reconstructions of the past are critically evaluated. It is in this context that a distinct archaeological theory comes to have relevance.

It is thus in my view entirely to be expected that the current rise in theoretical debate in the Netherlands should be linked (a) to the rise of 'institutions' (in a loose sense of the word) such as a TAG - like organisation, and (b) to debate about representation of the past, management and protection of the archaeological heritage I would differ from Slofstra in that I would suggest that the most important current stimulus for theoretical debate in the Netherlands will not be the intellectual advances of an historical-anthropological approach, but the new set of theoretical practices surrounding the whole issue of cultural policy and heritage management. It is in this 'critical' area that a role for reflective theory may be found.

In many ways, New and processual archaeology were primanly about method They were concerned with field and analytical procedures, hypothetıco-deductive methods and sampling strategies It is post-processual archaeology which has focussed on theory and identified the theoretical inadequacies of 1ts predecessor I would argue, despite Slofstra's claims, that both the trends identifiable in current Dutch theory are post-processual. Certainly, the commitment to history in the histoncal-anthropological approach is part of the wider re-integration of history found in all the social sciences and is readily identifiable as one of the key attributes of a post-processual approach. Equally, the embrace by young Dutch archaeologists of 'critical archaeology' is parallel with the critical stance which is the hallmark of post-processual debates. Slofstra may be right that these two aspects of Dutch archaeology do not denve from the Anglo-Saxon discussion, but they are none-the-less post-processual. I would suggest that their basis is the rise of a fully theoretical debate, itself made possible by a new set of practices which generate reflexivity.

\title{
ANOTHER PARTICIPANT'S VIEW ON DUTCH ARCHAEOLOGY IN POSTWAR TIMES
}

\section{Leendert P. Louwe Kooijmans}

Introduction In my opinion, Slofstra's description of the recent developments in Dutch archaeology can be charactenzed as a rather subjective narratio of a small episode in the history of science by a participant observer It is only in the last sentence of his paper that he - rather obligatonly - acknowledges his position. Primarily, the article is a compilation of personal experiences, memories and convictions based on a thorough study of the literature, but lacking interviews with the principal characters. It is very much a private account, even to such an extent that it would not be difficult for anyone involved in Dutch archaeology to point out the author. The paper tells us as much about Slofstra as about the history of archaeology and 
presents a very personal view on the development of our discipline the disqualification of the cultural-historical approach persisting into the eighties, the myth of the deliverance by the 'Historical-Anthropological Approach', together with the uncritical reiteration of the greatness of Van Giffen, and the 'conspiracy scenario' towards the 'academic establishment' which can retard everything except demographical processes

I am very much aware that, ever since the sixties, I have been a participant observer as well, although with a different education, a different network of connections, first-hand knowledge of a very different section of the same small discipline, and different appreciations, ambitions and responsibilities No doubt, also in the case of this review, it will be easy to point out its source It is the comment of a physical geographer transformed into a prehistorian, educated at the Universities of Utrecht and Leiden, in the period 1966-1982 employed by the National Museum of Antiquities (in prewar times the antipode of Van Giffen), and subsequently un1versity professor in Leiden To facilitate the interpretation and appreciation of his argument, Slofstra should have begun his paper by introducing himself in a similar way

It is clear that my comment could be deemed to be reactionary, unappreciative of new developments and in defence of the existing power-structures The following is not going to be a pompous theoretical counterstroke, but a simple argument by someone who values other facts higher and who only partially recognizes his own history in the article I disagree with the author on many aspects, but I realize that in this comment I will have to restrict myself to some major issues

I consider Slofstra's main thesis to be as debatable as the ones produced by Waterbolk and Bloemers, both of which were criticized by Slofstra However, these theses should be considered as personal views and certanly not as stereotypes Moreover, Waterbolk's opinion has been incorrectly reported he did notice developments, also in his own publications I agree with Slofstra that Bloemers' conception of a traditional Kuhnian crisis has to be considered as too excessive and cannot be supported by the avallable evidence Of course, there were discussions and several colleagues, perhaps even small groups of scholars, who had different opinions, but a crisis and a fully new paradigm ? No, that is really out of the question

Van Giffen If Slofstra really had intended to approach our discipline from a scientific-historical perspective, then he should have separated the period 1910-1940, which was characterized by a clash between two different personalities, with Van Giffen at first losing from Jan Hendrik Holwerda (1873-1951) who was 11 years his senior, but subsequently surpassing him, if only because he retired 17 years later than his competitor - in 1956 as compared with 1939 - but also due to his research capacities This is hardly the time nor the place for a detailed analysis of this controversy, but I consider it relevant to have a closer inspection of the important role regularly attributed to Van Giffen

Indeed he was dynamic and ambitious, but also relentless and dominant In the early years of his career he felt unappreciated and frustrated by Holwerda, Sen1or and Junior, and he soon developed into an angry young man At first he lost the game, but soon he went his own way, opposing Jan Hendrik Holwerda in many ways He did everything exactly the other way round, laying emphasis upon opposites He was better in many aspects but not in all How 'great' would Van Giffen have been without this controversy, which was largely developed by 
himself Can we trace a parallel to some of the controversies of the seventies and (see below) the period around 1950?

In response to Holwerda's lack of accuracy, culminating in the notorious mismeasurement(s) at the Arentsburg excavations, Van Giffen developed a hyper-accuracy and a strict methodology Excavating was elevated into an art, with the indeed convenient 'quadrant method' as the most prominent example The fact that Holwerda was paying so much attention to artefacts (as a scientist and as a museum curator) was contrasted with a disregard for these 1tems by Van Giffen and a focus on soil traces, stratigraphy and context of finds, the weak points in Holwerda's approach Van Giffen worked in a strictly empirical and analytical manner as opposed to the more intuitive and histoncal interpretations of his opponent Whereas Holwerda wrote a number of syntheses and a series of books for a wide audience, Van Giffen largely restricted himself to (unreadable) excavation reports It is also very interesting to examine the competition between Leiden and Groningen in a geographical sense the Netherlands might be seen as a large chess-board with the excavations as chess-pieces Thus we see the Leiden curator Bursch excavating in Frnesland (traditionally Van Giffen territory) when the local collector Popping and Van Giffen were on bad terms with each other This is just one example out of many Both sides were, however, fully controlled by the dominant cultural-historical paradigm of those days

I have the impression that the importance of Van Giffen for post-war archacology has been exaggerated His most important heritage is the accurate and clean method of excavation and the careful interpretation of soil sections and soil traces, as well as the large data base that he has left us However, his contributions to both palaeo-biology and basic research topics have been greatly exaggerated Especially Glasbergen followed in his footsteps, but he cannot be considered to be representive of the main stream in research in postwar times

The beginning of functionalism 1945-1955 The assumption that Dutch archaeology was still predominantly cultural-historical in approach and character well into the eighties is, in my opinion, incorrect and unjustified when we interpret the term 'cultural-histoncal' in the sense of the tradition of Kossinna and the early Childe, $1 \mathrm{e}$ the main objective being the chronogeographical definition of archaeological 'cultures' and the establishment of their typological relations and developments On the contrary, in my perception the penod 1945-55 represents the start of a new stage in Dutch archaeology This period is the formative phase of presentday archaeological practice I would like to discuss this period in some detail since Slofstra seems to overlook the essential part of $1 t$

Beside cultural history, the early years of scientific archaeology in Europe were characterized by yet another approach, identified by Trigger (1989) as functionalism In this approach, the main issue concerned daily life, $1 \mathrm{e}$ the study of societies with regard to their technological, economical and social aspects It was based on the investigation of settlements, with much attention being pard to palaeo-biological components Such an approach can already be discerned in the middle of the last century, especially in Denmark (Worsaae), Switzerland (Heim), and the Netherlands, 1 e in the Drenthe survey, the Arentsburg excavation and other mult1-disciplinary research by Reuvens The roots of functionalism in response to cultural history are traditionally accredited to be C Fox's Archaeology of the Cambridge Region (1923) 
and the work of the Fenland Research Committee in the decade before World War II (Clark 1933). Childe's work exemplifies a shift in this direction as well, see for example his settlement excavations at Skara Brae (1931). Of course, both approaches cannot be fully separated, nor can they be seen as opposite 'schools', but they certainly represent two different styles of research artefact classification versus a geographical/ecological approach to features.

A similar shift took place in the Netherlands, but not in the work of Van Giffen: after his spectacular and successful excavations at Ezinge, settlement research was left to 'slumber' (Waterbolk 1979a, 24). Only after the second World War did archaeology change in character, although I cannot point out distinct social or scientific causes for this process. Archaeology developed into a kind of human geography, first by Modderman's work in the penod 1945-55 and subsequently, from 1954 onward, by Waterbolk, 1.e. alongside and after Van Giffen. Apparently, next to evident appreciation of Van Giffen, the need was felt to establish individual research lines and to break away from his dommance.

After concluding his wartime research in the Noordoostpolder, Modderman was particularly inspired by the soil scientist Edelman, designer of extensive soil surveys on a landscape genetıc basis, especially in the central Rhine/Meuse river clay area. As a result of his (archaeological) contrubutions to these surveys, Modderman developed a great interest in the geographical aspects of archaeology and notably in the relationship between site and landscape, between archaeology and geology. This is exemplified, not only in his survey reports from the period 1945-53, but also by his later work. Modderman's excavation at Hekelingen in 1950 (in the same year as Clark's excavation at Star Carr!) can be considered a milestone. For the first time soll science, palaeobotany, archaeozoology and prehistory were combined into one project (Modderman 1953). Modderman's excavations in Sittard (1953-54), Santpoort (1955, publication 1960-61) and Elsloo/Stein (1958-66) made this kind of settlement research the style of the State Service for Archaeological Investigations (ROB)

It is tempting to consider the developments on both sides of the Channel as being interlinked in one way or another, but Modderman has assured me that this was not the case. The common interest generated the (later) contacts, not the other way round. Modderman met Childe, Hawkes and Clark for the first time around 1948 at a congress of the Union International de Ethnographie et Préhistore in Brussels and he subsequently participated (together with Van Giffen, Glasbergen and Glazema!) in a course of the British Council in Salisbury in 1949, in which Clark, however, did not take part. These contacts provided important add1tional inspirations for a geographical archaeology. In 1953, when Modderman stayed with Childe in London for 3 weeks and with Clark in Cambridge for a further 3 weeks, the report on Hekelingen was already in print

In 1954 the young biologist Waterbolk succeeded Van Giffen, and from that time onwards this new approach was also practısed in Groningen. Waterbolk started his excavations at the bandceramic settlement in Geleen, following in Modderman's footsteps. Next, the investigations at Vries (1957) and Wijster (1958-61) initiated a long series of settlement excavations on the 'Frisian/Drenthian Plateau'. The study, on the basis of regional surveys and the excavations mentioned above, of the evolution of settlements, settlement systems and occupation patterns of this region, from the Neolithic up to historical times, constitutes a main research topic of the Biological-Archaeological Institute and was Waterbolk's life's work. Waterbolk 
told me that his perspective has always been different from that of Van Giffen, as a result of his palynological research on large peat sections, in which not separate events but gradual and long term changes were reflected Van Giffen, however, continued to see pre- and protohistory as a sequence of distinct and separate phenomena or 'cultures', that had to be explaned by successive immigrations

It was Waterbolk who provided palaeo-biology with a firm and structural basis, first with h1s thesis De prehistorische mens en zyn milieu ('Prehistoric man and his environment', 1954) and subsequently with the appointment to his institute of Clason (1955) and Van Ze1st (1961) There is something curnous about Waterbolk, our most important archaeologist of the postwar period On the one hand, his approach differs considerably from Van Giffen's research on settlements, broad syntheses On the other hand, he belittles his own innovations by his sincere admiration for Van Giffen, who receives more credit this way than he deserves It is significant that not until the late seventies a palaeobotanist was appointed to the State Service and only in 1961 one (W Groenman-van Waateringe) to the Institute for Pre and Protohistory (IPP) in Amsterdam, years after Van Giffen had retıred

Thus, in the years 1945-53 the foundations were la1d for a completely new line of research, which took shape in the pernod 1953-59 and eventually would characterize Dutch archaeology the large scale excavation of settlements, linked with palaeo-ecological investigations As mentioned above, the most important heritage of Van Giffen consisted of the accurate field registration, the clean and strict excavation technique, and the careful soil interpretation Apart from these aspects everything appears to be new, particularly the research topic, and this was also the way the participants expenenced it and presented it in the years 1959-65, when I attended university Instead of bunal structures and cultural (nter)relations, settlements and the way of life had become the main 1ssues, together with environmental research, geograph$1 \mathrm{cal}$ aspects and the study of mobile artefacts Van Giffen viewed house plans as no more than just another type of artefact (in a Childean cultural sense), but from now on they were primarily considered a source of information about former societies This represented an original Dutch development, in which the investigators dismissed rather than continued Van Giffen's work, supported by the knowledge that simular interests had been developed on the other side of the Channel

This ant1-cultural-historical attitude can also be attested to in the traming and education programme in the sixties, which can best be illustrated by the textbooks that were most prominent in those days In Leiden these books were 1) Eggers' Einfuhrung in die Vorgeschichte (in a Dutch paperback edition) with an extensive review of Kossinna's Ethnische Deutung, 2) Grahame Clark's Archaeology and Society, its main theme being archaeological context as contrasted with former living societies, and 3) his Prehistonc Europe, the Economic Basts, my favourite book, at any rate in those days In the Netherlands, De Laet's excellent book Archéologie et ses Problemes unfortunately did not attract the attention that $1 \mathrm{t}$ deserved In an earlier paper (Louwe Kooljmans 1987b) I have suggested that the 1deas of the later New Archaeology and Archaeological Formation Theory already were the main issues in these books, be it that they were less strictly formulated These books reflect the way of thinking of young archaeologists in those days

All of this does not alter the fact that the 'old line' of barrow and cemetery research was 
continued as well, coupled with the Van Giffen style of documentation and interpretation, be it mainly as rescue archaeology: the major examples are Glasbergen (Toterfout in 1950), Modderman (Central Netherlands in 1952), and the later urnfield excavations by Verwers and Koo1

A special mention has to be made of the flourishing typochronological studies of artefacts, concerning all periods. This phenomenon must be percerved as a deliberate compensation for the neglect of this essentral topic by Van Giffen (Waterbolk 1979a and personal communication) It was a prerequisite for the study of cultural change. Bohmers and Wouters studied the Late Palaeolithic and Mesolithic, Modderman the Bandkeramık, Bakker the TRB culture, Glasbergen, Van der Waals and (later) Lanting the Beaker and Hilversum cultures, Butler the bronzes, and Waterbolk the Late Bronze and Iron Age pottery. Indeed, for some researchers these studies seem to have become a goal in itself. The primanly typochronological research problem of Glasbergen's excavation of the Schnurkeramik settlement at Aartswoud in 1972 exemplifies this tendency (Van Iterson Scholten and De Vnes-Metz 1981). However, thus can be contrasted with the Vlaardingen research project (1959-65), a large scale reprise of Hekelingen, 10 years earlier.

The developments described above may be considered as not extremely important and labelled by theorists as a minor shift within the cultural-historical paradigm, but such a point of view does not fit in with the experiences of the participants. Functionalism is not a slightly modified cultural histonctsm. The 'rupture' in Dutch archaeology during the period 1945-55 has been more fundamental and at any rate more general than the one at the begunning of the New Archaeology and the Contextual Archaeology, 25 and 35 years later, respectively

The reception of the New Archaeology With this characterization of Dutch archaeology as functionalistic we will have to take another look at the reception of the New Archaeology, or better: of the reservations towards it I agree with Slofstra that this attitude is owing to the field-oriented, soft (natural) scientific and a-theoretical character of Dutch archaeology, but I must add that exactly this character is a part of Van Giffen's heritage in the new research style. I wonder what the developments would have been if Van Giffen would not have used Holwerda as an opponent, but if both had managed to join forces, or the histoncal approach of Holwerda would also have influenced later developments I realize that such questions are a-historical, nevertheless they force themselves upon me. Indeed, at the time everybody felt uncomfortable with social theory and the philosophy of science. This situation was hardly ameliorated by the overdose of rhetoric used by New Archaeologists, which resulted in responses like that by Waterbolk (1974), to me not only equally unreadable, but with a similar overkill. However, I would like to reverse Slofstra's second argument it was not a contrast with the cultural-histoncal approach, but partly a feeling of recognition. I read in David Clarke's Analytical Archaeology that above all he attempted to systematize current archaeological practice To quote an opinion 'New Archaeology is a reaction to American practice, and not meant for us'. In my circle of acquaintances Analytical Archaeology was considered interesting, it was extensively discussed, but the question remained: how to apply all these principles and 1deas? The opposition of archaeological and systemic context, the polythetic definitions, the 
use of models, the more conscious deductive research strategy, all these aspects were appreciated, but the ngorously scientific approach and the dogmatic work with laws and rules much less. As Slofstra correctly states, we were much more susceptible to the more practical ways of thinking of geographical analyses and (slightly later) the archaeological formation theory. Together with certain technical innovations (computer application, individual find registration), they have changed the discipline more than the New Archaeology did. Did one excavate before without stating research problems?

I think that we, as rational Dutchmen, especially looked at what this all meant in practice and how those, presenting themselves as New Archaeologists, performed in actual research. They fell short of our expectations. In my opinıon, Van der Velde fulfilled the claims best. Newell's conclusions on Bandkeramik flint turned out to be untenable, whereas his preliminary presentation of Bergumermeer leaves some questions unanswered, for instance the problems of the time depth and the palımpsest aspect of the site and its consequences for the interpretation of the settlement. The pottery studies by Van der Leeuw were not considered to be a fundamentally new approach

Slofstra emphatically presents his own Kempen Project, the Assendelver Polders Project of the University of Amsterdam and the Eastern River Area Project of Willems (State Service for Archaeological Investigations, Amersfoort) as renewing pieces of research. As far as I am concerned, the question remains as to what extent - setting aside the dressing up with a lot of general theory - these projects fundamentally differ in their methods and research problems from the Groningen University project in Drenthe directed by Waterbolk, the Maaskant/Oss project 1nitıated in Leiden by Verwers, subsequently directed by Van der Sanden and Van den Broeke, and now contınued by Fokkens, the Leiden University Bandkeramik investigations or my own neolithisation programme? To put it quite planly, I consider this a rhetoncal question. In spite of the profusion of theoretical considerations, field practice is largely the same, as are the basic reports.

My synthesis would be that the Dutch postwar research tradition was a good starting point for a critical and selective reception and adoption of the complex of ideas embodied in the New Archaeology It is obvious that personal differences of opinion had to occur, with Newell in an extreme position on the one side and a substantial body of archaeologists, that disregarded or altogether missed the theoretical discussion, on the other A considerable number of researchers in the intermediary space ventured into quantitative models of past societies, with varying success Bloemers (1980), Brandt and IJzereef (1980), but also Modderman (1970, 1985), Bakels (1978, 1982), Koo1 (1979) and Harsema (1980).

Research problems were more explicitly formulated and research strategies more consciously mapped out, data processing, including statistics, was introduced, as was individual find registration, for instance at Swifterbant, the research design of which was clearly inspired by that of Bergumermeer.

It is true, these developments resulted in some personal controversies in the small archaeological world, where not only theoretical arguments but also personalities were at stake, but there was never any question of schools and school fights Everything was too personal and intermittent Indeed, the small 'establishment' (Waterbolk, Modderman, Van Es, and who else?) might be considered to be conservative - is that not an inalienable characteristic of 
establishment? - and not inclined towards a rigorous swing-over, but in view of the preceding argument for good reasons This conservatism acted as a brake and natural buffer within the archaeological system, demonstrating its value when, in its turn, the attack was opened on the New Archaeology I have the impression that at present we are coping with the contextual/ post-modern/anti-positivist ideas in a similar, delayed and moderate way.

Historical-anthropological deliverance? In his long plea for an 'historical-anthropological' approach Slofstra fails to tell us what the term exactly stands for and what the fundamentally new aspect of this approach would be Fortunately, he has done so in some detal on earlier occasions (1982 et al., 1990), be it not in very accessible places. From these publications it becomes clear that he alludes to the ideas of Norbert Elias and especially his civilization theory (Uber den Prozess der Zivilisation). It is a proof of great intellectual power to be able to bridge the gap between separate discuplines, like in this case sociology and archaeology. The importance of the structuration theory for contextual archaeology is another example of the way in which our discipline can profit from such exercises. The same applies for much of Binford's ethnoarchaeological research The ultimate purpose of archaeology is to understand human societies and therr changes. So, it is not a matter for discussion whether we need social theory, but which, not whether we should look at the past from a histoncal and anthropological perspective, but whether this should be the histoncal-anthropological doctrne of Elias. I must not be too severe in my cnticism as I have not read the work of Elias Being a member of the 'salaried academic establishment', who has to spend most of his time on education and management, time to do so has been lacking.

I did read a series of reviews of Elıas' work (Corbey 1989, 1991, Kielstra 1981; Maso 1978) and they appeared to be rather critical and shocking At any rate, they do not justify the usurpation of the Leiden Pioner project Changing Views of Ice Age Foragers into the historicalanthropological approach, if only because an important critic of Elias, the cultural philosopher Corbey, is a promment participant in this project. How fundamental are these criticisms? Are they relevant for us? I do think so. I can mention the psycho-analytical roots in the Freudian equation of phylo- and ontogenesis, a Lamarckian evolutionıstıc way of thinking, the assumption of Selbstzwang as the driving force behind affect control, while Fremdzwang is more plausible, the specific relevance of Elias' conceptions for Western Europe, more precisely the developments in France, in the 16th - 19th century, the explanation of the rise and not so much the collapse or decline of (a) civilization and the western ethnocentric character of his ideas. These are criticisms that require some prudence in their application to other settings, such as the Palaeolithic or prehistory in general

If Slofstra intends to gradually transform all of us into historical anthropologists, by means of demographic processes and the power of his 'Kempen Group', he should first of all give us a concise explanation what this approach is all about and how it would work when applied to archaeology. Is it processual archaeology with a waft of ant1-positivism (Slofstra et al. 1982) or does it only mean that we should have an open eye for historicity and anthropological aspects of former societies? There is no question of any clash of paradigms in any of these options, not in 1982 and not in 1994 At any rate, there were not 'three cities' in theoretical respect and it is also questionable whether we should all be reasoning along the same lines 